\title{
American experience in the implementation of AML / CFT system
}

\author{
Dmitry Larin ${ }^{\mathrm{a}}$, Ekaterina Popova \\ Saint Petersburg State University of Economics, 191023 Sadovaya str., 21, St. Petersburg. Russia
}

\begin{abstract}
This article presents a research into very specific matters and issues of creating and further improvement of Anti-Money Laundering and Combating the Financing of Terrorism system (abbreviated as AML/CFT) in the USA. In contains a precise analysis of key elements of this system, as well as a deep look into the nature and purposes of financial intelligence "FinCEN". Strong emphasis is laid on The US Foreign Account Tax Compliance Act (FATCA) for the reason that, according to this Act, any foreign financial institution is legitimately forced to sign a special agreement with The US Internal Revenue Service (IRS), giving the Service power to maintain control over any American asset within its equity. The latter is understood as a legal right to investigate not only the accounts and property of American taxpayers, but to investigate any account or capital of any foreign institution having American shares or stocks.
\end{abstract}

\section{Introduction}

The United States of America was among the first countries to face money laundering and schemes of turning crime benefits into legal assets because of the high degree of the US economic sophistication. This is the reason why American government was early forced to confront such sort of crime. The financial authorities made their point in fighting toward any option and scheme aimed at the legalization of criminal proceeds, and a new legislative framework emerged.

\section{Legislation regulating the AML / CFT in USA}

The In 1970, Bank Secrecy Act (BSA) was adopted in order to combat illegal financial transactions through so called "hidden accounts" in foreign banks. In plain English, this Act instates supervision over every American-based remittance of more than ten thousand dollars, and sets standards and requirements provided with civil or criminal liability for their violation. In addition, an extensive network of regulatory bodies endowed with broad controlling functions was created to establish a close eye on intergovernmental financial operations in the USA.

The next and very important step in this war was the adoption of Money Laundering Control Act in 1986, which added money laundering in any form to the list of criminal offenses. MLCA identified three different types of criminal offense in the area of money laundering: -intentional and aware assistance in money laundering, provided by the financial institution;

-inducement to money laundering on a large scale (of more than 100000 US dollars in question) for the benefit of any third party;

-intentional and aware misleading of the financial authorities by separating large "dirty money" transfers into a series of small ones that are out of BSA restrictions.

The penalty for all these offenses varies from a fine reaching up to half a million US dollars, to double repayment of income proven laundered, to deprivation of property, or to imprisonment for a term of up to 20 years.

\section{The role of the Financial Crimes Enforcement Office («FinCEN»)}

A special place in the AML/CFT system is reserved for Financial Crimes Enforcement Network, or "FinCEN", an agency established to coordinate tasks and actions of any governmental organization involved into any particular investigation. In this, FinCEN shares similarity with the intelligence supporting role, but of a financial kind.

The main function of this body is to assist the US legal system at domestic and international levels. Today FinCEN is an analytical and informational center that collects, handles and organizes informational flow in order to support any investigation. FinCEN conducts no investigations into matters of money laundering by itself,

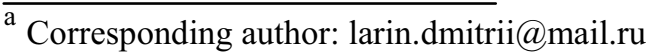


and only provides necessary data on request, thus playing an important role in maintaining national security and counter-terrorism investigations. Among the others, CIA, FBI and DIA enjoy the services provided by FinCEN.

In return, FinCEN has access to the data repositories of the CIA, military intelligence and National Security Agency. Having the last one on the list makes a great impact on FinCEN businesses, meaning that FinCEN has access to the NSA digital sources of information inside and outside of the USA.

In 1995, at the initiative of the FinCEN, US Treasury developed new rules governing the activities aimed at combating money laundering. Inter alia, these rules imputed banks to inform the regulatory bodies on a regular basis about all currency transfers exceeding the sum of 3000 US dollars. All information, as well as data, gathered under the Bank Secrecy Act imperatives, is further transmitted to the US financial authorities and to the FinCEN. FinCEN distributes this information into broad databanks listed below [2]:

Financial Database (FDB), the one submitted to allencompassing variety of financial reports of US banks and other financial institutions to regulatory bodies, including:

-currency Transaction Reports about transactions of more than a threshold amount;

-currency Transaction Reports by Casinos, or CTRCs;

reports of Foreign Bank and Financial Accounts, or FBAR;

-so called "8300 Report", a report of Trade/Business one-time income in cash, if it exceeds 10000 US dollars. This paper is filled by a business owner each time for every separate admission.

Financial Database also contains reports on suspicious transactions and international transfers, as well as handover of reference documents in case, if some piece of information is claimed by police or other responsible officials, or otherwise reserved for conducting financial crime investigation.

Private Information Databank contains reports on private and corporative property. They are sourced mainly from commercial analytical agencies and services, along with US Customs Service and Internal Revenue Service.

This list also includes the legal case index composed of US law enforcement agencies files. The index is divided into following groups:

-information Source Data Base;

-data Base of Undercover Money Laundering Investigations;

- criminal Referral Data Base.

Such index holds entries on any person who has ever faced charges in the USA. Suchwise FinCEN is able to provide law enforcement with all information necessary on request, thanks to the FinCEN large information network.

Since 1991, the Suspect Account Records service of FinCEN database, or SAR, has been put into action to monitor unreliable banking accounts.
Finally, FinCEN enjoys direct benefit from one more option - Treasury Enforcement Communications System by the US Treasury, shortly known as TECS II, providing FinCEN with comprehensive knowledge about financial condition of drug-dealing suspects, commercial banks under special supervision and related matters.

Superior AI systems and programming protocols allow FinCEN to constantly scan up to $60 \%$ of available databases in a routine mode, searching and matching different pieces of interconnected information from different sources into a single document (e.g. about a person, an entity, an organization...). In addition to financial researches FinCEN is involved into a new form of interagency cooperation called "Reports on criminal activity". This is an overall report, composed of all possible information by FinCEN, if required. The request can be sent if a bank, a law enforcement officer or a fiscal official has disclosed some suspicious action and asks for massive examination.

After FinCEN board, soon all of the aforementioned databanks are to be unified under the aegis of newest technology framework AI/MPP (MPP - Massive Parallel Processing). This step will make it possible to observe and supervise the entire banking traffic in the USA in real time.

FinCEN claims this surveillance is absolutely necessary for the purposes of searching and ceasing all illegal activities online on spot. Also, this AI system is currently under improvement aimed at identifying handwriting, detecting mistakes, numbers and decrypting abbreviations made when filling out the report by hand. FinCEN believes that it will allow watching over even the depository operations and private sector money transactions in real-time. In case of positive crime detection the local station of the tracking system alerts the Federal Computer Center, and the bank in question is warned to stop the operation. Thus the suspicious transaction will be aborted in no time.

Thus, with the creation of FinCEN the US financial authorities gained the ability not only to hold centralized access to all databanks on demand, but to analyze and compare gathered multisource information in short terms. According to Western experts, FinCEN actually runs the largest of all the existing databanks for today, the one that can simultaneously process and analyze truly grandiose amounts of information.

\section{The law "On Foreign Account Tax" as an extraterritorial mechanism of counteraction to legalization of the AML system}

In addition, on 1 January, 2013, the US Foreign Account Tax Compliance Act, also known as FATCA, came in full force. According to FATCA, financial institutions of any country of origin, addressed in the text as a "foreign financial institution", or FFI, must enter into a special agreement with Internal Revenue Service (IRS), designed for the monitoring purposes. This way, IRS keeps tabs on the presence of US taxpayers' accounts (or assets of foreign entities, where American taxpayers 
present a significant percent of shareholders) among FFI equities. Beginning January 1, 2014, this information stands to be transferred to the IRS. If FFI declines or simply lacks this agreement, it is subjected to a federal fine of $30 \%$ on:

-the total sum of currency transactions made from the US territory;

-the revenue made by celling American-based assets (e.g. bonds or stocks), with no limitation to was this deal actually profitable or not;

-all money transfers to FATCA non-participating organizations (this amendment will take effect after 2017).

The purpose of FATCA is hereby to introduce an extraterritorial mechanism of counteraction to out-ofborder legalization of earnings generated by US citizens and residents as a result of tax evasion.

Table 1. Elements of the American AML/CFT system.

\begin{tabular}{|c|c|}
\hline Legal base & $\begin{array}{l}\text { •Bank Secrecy Act (BSA), 1970; } \\
\text { •Money Laundering Control Act, } \\
\text { 1986; } \\
\text { Comprehensive Money Laundering } \\
\text { Act, 1986; } \\
\text { •Anti-Drug Abuse Act,1988; } \\
\text { •Crime Central Act. Par. 2532, } \\
\text { 1990; } \\
\text { •Housing and Community } \\
\text { Development Act, 1992; } \\
\text { •Presidential Decision Directive } \\
\text { (PDD) No 42, 1995; } \\
\text { •Foreign Account Tax Compliance } \\
\text { Act (FATCA), 2013 }\end{array}$ \\
\hline $\begin{array}{c}\text { Financial } \\
\text { Intelligence } \\
\text { Unit }\end{array}$ & $\begin{array}{c}\text { US Treasury Division - Financial } \\
\text { Crimes Enforcement Network (FinCEN) }\end{array}$ \\
\hline $\begin{array}{l}\text { Those } \\
\text { responsible for } \\
\text { informational } \\
\text { cooperation } \\
\text { with Financial } \\
\text { Intelligence }\end{array}$ & $\begin{array}{c}\text { Officials of financial intermediaries in } \\
\text { charge }\end{array}$ \\
\hline $\begin{array}{l}\text { Criminal } \\
\text { responsibility } \\
\text { for laundering } \\
\text { the proceeds of } \\
\text { crime }\end{array}$ & $\begin{array}{l}\text { Very significant (fees and imprisonment } \\
\text { for up to life sentence) }\end{array}$ \\
\hline
\end{tabular}

Two models of possible intergovernmental agreements are provided to put FATCA into effect. The data on American taxpayers are collected and processed by national financial authorities in accordance with the national legislation system. The information they gathered is then transferred to IRS in exchange for the same information from the US.

The second model is based on a special agreement between the USA and the national government in question that forces national financial organizations to share their databanks with IRS. And there is a strong and standing doubt about such course of action, which may uncontrollably violate the national laws regarding bank secrecy.

The countries that have signed agreements are (with the date of signing in brackets):

Finalised IGAs:

Model 1 IGA

-Australia (4-28-2014)

-Bahamas (11-3-2014)

-Barbados (11-17-2014)

-Belgium (4-23-2014)

-Brazil (9-23-2014)

-British Virgin Islands (6-30-2014)

-Bulgaria (12-5-2014)

-Canada (2-5-2014)

-Cayman Islands (11-29-2013)

-Costa Rica (11-26-2013)

-Curaçao (12-16-2014)

-Cyprus (12-2-2014)

-Czech Republic (8-4-2014)

- Denmark (11-19-2012)

-Estonia (4-11-2014)

-Finland (3-5-2014)

-France (11-14-2013)

-Germany (5-31-2013)

-Gibraltar (5-8-2014)

- Guernsey (12-13-2013)

-Hungary (2-4-2014)

-Honduras (3-31-2014)

-Ireland (1-23-2013)

-Isle of Man (12-13-2013)

-Israel (6-30-2014)

-Italy (1-10-2014)

-Jamaica (5-1-2014)

-Jersey (12-13-2013)

-Latvia (6-27-2014)

-Liechtenstein (5-19-2014)

-Lithuania (8-26-2014)

-Luxembourg (3-28-2014)

-Malta (12-16-2013)

-Mauritius (12-27-2013)

-Mexico (4-9-2014)

-Netherlands (12-18-2013)

-New Zealand (6-12-2014)

-Norway (4-15-2013)

-Poland (10-7-2014)

- Qatar (1-7-2015)

-Singapore (12-9-2014)

-South Africa (6-9-2014)

-Spain (5-14-2013)

-Slovenia (6-2-2014)

-Sweden (8-8-2014)

-United Kingdom (9-12-2012)

-Turks and Caicos Islands (12-1-2014).

Model 2 IGA

-Austria (4-29-2014)

-Bermuda (12-19-2013)

-Chile (3-5-2014)

•Hong Kong (11-13-2014)

-Japan (6-11-2013)

-Moldova (11-26-2014) 
-Switzerland (2-14-2013).

FATCA IGAs under discussion (The countries, having FATCA agreements under discussion but considered compliant to, are):

Model 1 IGA

-Algeria (6-30-2014)

-Angola (11-30-2014)

-Anguilla (6-30-2014)

-Antigua and Barbuda (6-3-2014)

-Azerbaijan (5-16-2014)

-Bahrain (6-30-2014)

- Belarus (6-6-2014)

-Cabo Verde (6-30-2014)

-Cambodia (11-30-2014)

-China (6-26-2014)

-Colombia (4-23-2014)

-Croatia (4-2-2014)

-Dominica (6-19-2014)

-Dominican Republic (6-30-2014)

- Georgia (6-12-201)

- Greece (11-30-2014)

-Greenland (6-29-2014)

- Grenada (6-16-2014)

-Guyana (6-24-2014)

-Haiti (6-30-2014)

-Holy See (11-30-2014)

-Iceland (11-30-2014)

-India (4-11-2014)

-Indonesia (5-4-2014)

-Kazakhstan (11-30-2014)

-Kosovo (4-2-2014)

-Kuwait (5-1-2014)

-Malaysia (6-30-2014)

-Montenegro (6-30-2014)

-Montserrat (11-30-2014)

-Panama (5-1-2014)

-Peru (5-1-2014)

-Philippines (11-30-2014)

-Portugal (4-2-2014)

-Romania (4-2-2014)

-Kitts and Nevis (6-4-2014)

-Lucia (6-12-2014)

-Vincent and the Grenadines (6-2-2014)

-Saudi Arabia (6-24-2014)

-Serbia (6-30-2014)

-Seychelles (5-28-2014)

-Slovak Republic (4-11-2014)

-South Korea (4-2-2014)

-Thailand (6-24-2014)

-Trinidad and Tobago (11-30-2014)

-Tunisia (11-30-2014)

-Turkey (6-3-2014)

-Turkmenistan (6-3-2014)

-Ukraine (6-26-2014)

-United Arab Emirates (5-21-2014)

-Uzbekistan (6-30-2014).

Model 2 IGA

-Armenia (5-8-2014)

-Iraq (6-30-2014)

-Macao (11-30-2014)

-Nicaragua (6-30-2014)

-Paraguay (6-6-2014)
-San Marino (6-30-2014)

-Taiwan (6-23-2014).

With the recognition of the FATCA first model at international level, one multinational informational field can be created, and this process met approval in the most countries. The shared database is designed to make financial information about accounts and transactions inside national banking systems available to international law enforcement and governmental bodies in charge.

Through this cooperation, tax havens will lose a part of their attractiveness, and white-collar criminals are going to be cut off from the main instrument of obscuring their assets. In other words, under the influence of FATCA, the international AML/CFT system is reorganized in a sense of reaching a new level of state-to-state interaction and revising of national legislation.

To sum it up, authors must confirm the USA having one of the most effective AML/CFT systems to date, due to its desperate need to supervise the largest world economy and to maintain control over a wide variety of financial institutes both of international and state levels.

There are also other far-reaching consequences arising out of the international nature of FATCA. National legislations, not to mention Russian, now face the necessity to keep in view this new proposed level of bank secrecy and fiscal cooperation. Assuming the predominant support of FATCA requirements, the global banking system may have to switch to a higher transparency and higher level of governmental control.

At the global level of law enforcement cooperation, the AML/CFT system will highly increase the intensity of informational exchange on persons and organizations facing charges of tax evasion and criminal activity, thus boosting the effectiveness of money laundering combat.

So, American experience demonstrates a positive example of Financial Crimes Enforcement Network establishment. This solution now provides the country with informational processing and analytical support, a good ground for financial research and investigations. Law enforcement now relies greatly on the FinCEN capacities, and this mutual partnership goes well beyond tax crimes: CIA, FBI, DIA and others use FinCEN capability to do necessary research in matters involving espionage and high crime.

FinCEN can also find great use as a testing and programming facility for different US nuclear nonproliferation, counterterrorism and counterdrug strategies. In this area FinCEN analysts, working together with experts from DEA, DIA and Los Alamos National Lab, did their part in creation of Counterdrug Modeling and Simulation System (CMASS). The CMASS imitates methods of drug delivery, insurgency guerilla and terrorist attacks planning to predict reaction to the US law enforcement tactics.

The last but not the least, FinCEN should be mentioned to operate at the international level of cooperation - far beyond the United States borders.

As a conclusion of this research, authors would like to point out the successful features of the American AML/CFT system and beneficial characteristics of its implementation in the USA. For obvious reasons, 
authors propose that this experience should be taken into careful account when forming Russian Anti-Money Laundering and Combating the Financing of Terrorism systems.

\section{References}

1. E. Dementieva, SIBIR Publishing (2008)

2. R. Zhubrin, Walters-Clover Publishing (2011)

3. FinCEN. The Money Laundering Regulations (2007)

4. Global Anti-Money Laundering Vendor Evaluation: A Reinvigorated Market, Waters Rankings (2010)

5. Roger S. Wise, Mary Burke Baker, Journal of investment compliance, 13, (2012)

6. C. Graffy, The Wall Street Journal, Oct., (2015)

7. L. Saunders, The Wall Street Journal, Oct., (2015)

8. International Monetary Fund. Review Of The Fund's Strategy On Anti-Money Laundering And Combating The Financing Of Terrorism, Feb. (2014)

9. International Monetary Fund. Global Financial Stability Report, Oct., (2015)

10. FinCEN. Money Laundering Prevention, Washington DC (2015)

11. United Nations Office for Drugs and Crime, CTITF Working Group (2009)

12. J. D'Souza, Terrorist financing, money laundering, and tax evasion, (Taylor \& Francis, 2012)

13. S. Krook, FATF, 3, (2013) 